This is an Accepted Manuscript of an article published by Springer in Human Ecology, on September 2019, available online on:

\title{
Belowground and aboveground sustainability: Historical management change in a Mediterranean agroecosystem (Les Oluges, Spain, 1860-1959-1999)
}

Lucía Díez $^{\mathrm{a}^{*}}$, José Ramón Olarieta ${ }^{\mathrm{b}} \&$ Enric Tello ${ }^{\mathrm{a}}$

${ }^{a}$ Department of Economic History, Institutions, Policy and World Economy, University of Barcelona, Barcelona, Spain; ${ }^{b}$ Department of Soil Science and Environment, Engineering School of Agriculture (ETSEA), University of Lleida, Lleida, Spain.

*Corresponding author: Lucía Díez Sanjuán, Department of Economic History, Institutions, Policy and World Economy, Faculty of Economics and Business, University of Barcelona, Office 2432, Diagonal Avenue 690, 08034 Barcelona, Spain; email: luciadiez@ub.edu 


\begin{abstract}
This paper studies the historical evolution of the farming practices linked to the maintenance of soil fertility in a semi-arid Mediterranean village. We analyse the agroecosystem from a sociometabolic perspective at three different points in time (c.1860, 1959 and 1999), focusing on the estimation of the nutrient balances and connecting the assessment of the belowground sustainability with the aboveground dimension of the agroecosystem management. Nutrient balances at the aggregated scale were more equilibrated in 1860 and 1959 (with results between -6 and $1 \mathrm{~kg} \mathrm{ha}^{-1}$ ) than in 1999 (with nutrient surpluses over $86 \mathrm{~kg} \mathrm{ha}^{-1}$ ), but at the crop system scale nutrient deficits existed at all the points in time. We discuss the complexity of sustainable farming management assessing the efficiency, accomplishment and durability of the fertilization techniques. Our conclusions highlight the unsustainability of industrialized agriculture and the value of integrated management of agroecosystems to improve agricultural sustainability.
\end{abstract}

Keywords: Nutrient balances, Agricultural sustainability, Social Metabolism, Traditional agricultural management, Agroecology

\title{
1. Introduction
}

Mediterranean ecosystems have been managed by humans over millennia transforming and adapting their societies and the environment in a process of coevolution in which agriculture played an important role (Blondel 2006; Agnoletti and Emanueli 2016). Agricultural systems are shaped by biophysical and socioeconomic factors, which 
determine the adoption of different management practices. Since the spread of the Green Revolution throughout the second half of the $20^{\text {th }}$ century, Mediterranean agroecosystems experienced a great transformation. Traditional agricultural practices were locally adapted and fundamentally depended on organic resources, while modern agricultural methods can be characterized by their use of technologies and industrial external inputs largely dependent on fossil fuels. This transformation has entailed a series of environmental problems that challenge the sustainability of industrialized agriculture. In order to overcome the flaws of modern agricultural management the study of traditional farm systems is gaining attention as a source of valuable knowledge for a sustainable design and management of current and future agroecosystems (Bignal and McCracken 2000; Altieri 2004; Eichhorn et al. 2006; Plieninger et al. 2006; Martin et al. 2010; Barthel et al. 2013).

This paper analyses the historical transition of the agroecosystem of Les Oluges, a small village in Lleida province (Catalonia, Spain), from traditional organic farming in the mid$19^{\text {th }}$ century to a fully industrialized agricultural system in 1999 . With its own specificities, the historical transformation of Les Oluges is representative of the changes experienced in many cerealist Mediterranean agroecosystems. The analysis is grounded on the perspective of Social Metabolism, focusing on the material dimension of the exchange of energy and materials between society and the environment, and acknowledging that this exchange is mediated by culture (González de Molina and Toledo 2014). Furthermore, the analysis of the agrarian metabolism of Les Oluges follows an agroecological approach considering that the flows of energy, water, and the cycling of nutrients are the most fundamental processes in agroecosystems, and human intervention is a key determinant of the functioning of these processes that distinguishes them from wild ecosystems (Gliessman 2015). Farmers maintain the productive capacity of the 
agroecosystem by a continuous investment of external energy through their labour, material inputs and information, and by managing the resources available to replenish the nutrients extracted through harvest. Thus, the sustainability of an agroecosystem can be assessed by looking at how the different human management practices affect the flows of energy carriers and the cycling of nutrients that play a vital role in the reproduction of their renewable living funds (i.e. farmland, livestock-barnyard, farm-associated biodiversity, and farming community). Aboveground, the flow of energy has to keep some level of efficiency in terms of the energy needed to produce a unit of energy output to be sustainable in the long run (Tello et al. 2016), and the rate of extraction of resources cannot exceed the rate of regeneration of the funds. Belowground, a sustainable cycling of soil nutrients must also show an equilibrium between inputs and outputs. This will be assessed as the efficiency of the fertilization practices. Sustained deficits in the long term can involve soil nutrient mining and lead to a reduction of cropland fertility and productivity. Conversely, surpluses of nutrients can also create a loss of productivity and/or pollution problems. Ultimately, these imbalances can damage soil fertility, although many other processes and elements may affect belowground sustainability beyond nutrient cycling (Neary et al. 1999; Garcia-Ruiz et al. 2012), such as soil physical characteristics, nutrient and water storage capacity, organic matter content and belowground biodiversity. Even though the historical resources available do not allow us to develop an in depth analysis of all of these conditions, we will provide an approximation to these issues by assessing the accomplishment of the fertilization practices. Finally, our assessment of belowground sustainability considers also the durability of the management practices regarding the renewability of the fertilizing sources employed. 


\section{Methodology}

\subsection{Nutrient balances}

We calculate the nutrient balances for the three main macronutrients: nitrogen $(\mathrm{N})$, phosphorus (P) and potassium (K). The methodology employed is based on previous studies for various Mediterranean agroecosystems at different scales (Garrabou and González de Molina 2010; Garcia-Ruiz et al. 2012; Galán del Castillo 2015). We consider the following flows of nutrients:

-Human outputs: crops extraction (main produce and by-products)

-Human inputs: seeds, irrigation, buried biomass, manure (which includes humanure in 1860 and 1959), burnt biomass (formiguers ${ }^{l}$ ), and mineral and synthetic fertilizers.

-Natural outputs: gaseous losses of $\mathrm{N}$ and leaching.

-Natural inputs: atmospheric deposition, and symbiotic and non-symbiotic $\mathrm{N}$ fixation.

Nutrient balances are a useful but limited tool for assessing the maintenance of soil fertility through agricultural management (Öborn et al. 2003; Oenema et al. 2003). First, nutrient balances do not cover all the physical and biological processes involved in the complex phenomenon of soil fertility. Some important conditions and characteristics of soils are left aside, such as soil rootable depth, texture and structure, cation exchange capacity, $\mathrm{pH}$, salinity, organic matter and soil biota. A second limitation of the nutrient balances (shared with the reconstruction of the energy balances) is that it is not possible to obtain all the necessary local or on-site data, especially for their historical

\footnotetext{
${ }^{1}$ A formiguer was a heap of shrubs and small tree branches that was burnt under a soil cover in the cropland. Then, the ashes and charcoal were spread and buried into the soil.
} 
reconstruction. However, the balances of $\mathrm{N}, \mathrm{P}$ and $\mathrm{K}$ presented in this work contain the most relevant fluxes of these nutrients, and the lack of data has been offset using available historical sources from similar nearby agroecosystems and from modern studies that consider similar ecological conditions. Even though the results need to be interpreted with caution, they still offer an important insight into the long-term evolution of the agroecosystem sustainability.

The nutrient balances of Les Oluges have been calculated at two different scales. Aggregated results at municipal scale give an account of the total capacity of the agroecosystem for the replenishment of nutrients extracted within this boundary. In this respect it is important to acknowledge two limitations of this analysis. Firstly, given the lack of information about the flows of nutrients into and out of Les Oluges, we have assumed that the cycling of nutrients is confined to the administrative limits of the municipio $^{2}$, even though this was probably not the case in the past and is certainly not so in the present. Secondly, the data available for some flows of nutrients cannot be extrapolated to the municipal scale. We have dealt with these limitations specially in the estimation of the flows of nutrients corresponding to manure and soil erosion, as explained in the next section.

A positive result at the municipal scale does not mean that soil nutrients are being replenished for all the land uses and particular plots. To complement this perspective, the nutrient balances for each type of crop system have been estimated. This approach allows us to appreciate the different management practices that might have been employed on each crop system and their capacity to sustain soil fertility.

\footnotetext{
${ }^{2}$ A municipio (municipality or township) is an administrative unit composed by the built village centre and the surrounding rural areas of cropland, woodland and pastureland with some scattered farms or isolated buildings linked by a network of roads and paths.
} 


\subsection{Estimation of the main flows of nutrients}

The structure of the agroecosystem was built using different historical records. Land-use registers and cadastres of the municipio provided cropland composition and the distribution of farmland among cropland, woodland, pastureland and urban uses. Additionally, information obtained from cattle census and local population registers determined the sizes of the livestock-barnyard complex and the farming community. The flows of nutrients were calculated from the structure of the agroecosystem.

Crop extractions was estimated multiplying the yields obtained according to local agricultural surveys by the nutrient contents of each crop according to Soroa (1953), Fernández-Escobar et al. (2015) and Galán del Castillo (2015). From these crop extractions, the amounts of nutrients reintroduced on cropland as seeds and buried biomass (stubble and vine pruning) were estimated.

The calculation of the volume of water used for irrigation was based on Vicedo i Rius et al. (1999) considering the different yields from rainfed and irrigated yields of wheat in Les Oluges. The resulting volume of water used for irrigation was $1900 \mathrm{~m}^{3} \mathrm{ha}^{-1}$ in wheat and olive groves, and $3300 \mathrm{~m}^{3} \mathrm{ha}^{-1}$ in vegetable gardens. The concentrations in $\mathrm{N}, \mathrm{P}$ and K of the water used were obtained from Galan del Castillo (2015).

The availability of manure was estimated from the livestock-barnyard composition, excluding the losses during grazing and including animal beds. Additionally, manure in 1860 and 1959 includes human excreta. The total nutrients available for fertilization from manure exclude also the losses during composting and storage of the heap. The local sources available for 1860 and 1959 (JCA 1890; Soroa 1953) provided the information about the distribution of manure among crop systems and the doses applied. For 1999, manure was applied up to the maximum legal dose: 170,75 , and $130 \mathrm{~kg}$ of $\mathrm{N} \mathrm{ha}^{-1}$ for 
cereals, almond trees, and irrigated olive groves respectively. Given the large availability of manure in 1999, it was possible that flows of manure between the municipio of Les Oluges and nearby territories existed. It was not possible to obtain data for 1999, but current data revealed that the amount of local hectares fertilized with external manure is similar to the amount of external hectares fertilised with local manure (20\% of cropland approximately). These fluxes would thus cancel each other and we excluded these flows from our balances.

For estimating the flows of nutrients from formiguers we followed Les Oluges agricultural survey (cartilla evaluatoria) of 1883. We estimated their size and the number of formiguers built in each crop system on the basis of their monetary value. The effectiveness of formiguers for the management of soil fertility has long been debated (Roxas Clemente 1808). Modern experiments show that, further from the direct input of $\mathrm{N}, \mathrm{P}$ and $\mathrm{K}$ in charcoal and ashes, the mineralization of organic matter caused by the heat of the formiguer produced a flush of plant available $\mathrm{P}$, while the loss of mineral $\mathrm{N}$ during burning was compensated in the short term by an increase in the mineralization of organic $\mathrm{N}$ afterwards. Additionally, formiguers helped to reduce weeds and pests, and aided in 'loosening' the soil (Mestres and Mestres 1949; Olarieta et al. 2011). In this work, the nutrient contribution of each formiguer was estimated following the results from Olarieta et al. (2011).

The information about the use of industrial fertilisers was obtained from local informants. According to these, the doses applied in the mid- $20^{\text {th }}$ century were $1 \mathrm{~kg}$ of guano per $\mathrm{kg}$ of seeds, and $1 \mathrm{~kg}$ of ammonium nitrate per $\mathrm{kg}$ of seeds, and they were only applied on cereals. In 1999, the doses applied were $7,000 \mathrm{~kg} \mathrm{ha}^{-1}$ of a compound fertilizer $2 / 2 / 1$ (which provides $140 \mathrm{~kg}$ of N, $140 \mathrm{~kg}$ of $\mathrm{P}$ and $70 \mathrm{~kg}$ of $\mathrm{K}$ ) and $270 \mathrm{~kg} \mathrm{ha}^{-1}$ of "spring nitrate", which has been considered to be calcium ammonium nitrate with a $27 \%$ content 
of $\mathrm{N}$. However, the total $\mathrm{N}$ applied according to the doses in $1999\left(213 \mathrm{~kg}\right.$ of N ha $\left.{ }^{-1}\right)$ is above the legal allowed (120 kg of $\left.\mathrm{N} \mathrm{ha}^{-1}\right)$. Since both legal and local informants doses resulted in large surpluses of nutrients, the results showed in the paper correspond to the mean between them.

The distribution of manure and industrial fertilizers in 1860 and 1959 has been estimated considering the different soil qualities recorded in the sources consulted. According to the historical records of 1860 , the distribution of crops and fertilizing resources were linked to the quality of the soil: best quality soil was sown with wheat and received greater fertilization, while medium and lowest quality soils were sown with barley and rye respectively and received lower doses of fertilization. All the cereal crops in 1860 were left fallow every other year. In the same vein, for 1959 we have considered that wheat was fertilized with mineral fertilizers and was left fallow one every five years, while barley and oat only received manure and were left fallow every other year. In 1999 there is no distinction among soil qualities, and the distribution of fertilizing sources was made considering the records of fertilized surfaces, which indicate that irrigated olive trees and $10 \%$ of the almond trees were fertilized. For cereals, we distributed first the manure, until the maximum legal dose, and once all the manure was applied, we considered the remaining hectares fertilized with industrial fertilizers.

The flows of other inputs and outputs have been estimated following different sources that provided data for ecological conditions similar to our agroecosystem (Harris 1988; Bosch Serra et al. 2007; Galán del Castillo 2015; Peoples et al. 2016).

Fallow was also a widespread practice for managing soil fertility in traditional agriculture, especially in arid and semi-arid climates (Robertson et al. 2010; Gliessman 2015). However, fallow is not a fertilizing method in terms of nutrient replenishment, but a way 
of managing soil fertility by increasing the water stored on the soil, and by helping to control weeds, diseases and pests (Shiel 2006; Oliver et al. 2010). In order to show the relevance of this management we have differentiated the input of nutrients through the natural processes of deposition and non-symbiotic $\mathrm{N}$ fixation that occur in fallow land including the label 'fallow' in the nutrient balances at the crop system scale.

Finally, we have not included the nutrient losses caused by soil erosion because, at the aggregated scale, the soil erosion that affected mainly platforms at the top of the hills, would be cancelled by the deposit of these sediments in the valley floors and terraced slopes. At the crop system scale, it was not possible to make proper estimations of the distribution of land uses and crop systems for all the points in time studied, as would be needed to determine soil erosion and formation. However, in this respect it is important to highlight the existence of terraces, an ancient form of soil conditioning aimed at improving cropland fertility, but not at the replenishment of nutrients. Dry-stone terraces were an important element of traditional biocultural landscapes (Agnoletti and Emanueli 2016). In Les Oluges, they were originally built not only for flattening slopes and increasing the land suitable for cultivation, but also as way of reducing soil erosion and managing surface runoff (Olarieta and Padró 2016). The construction and maintenance of terraced systems, linked to traditional management practices and knowledge (Sandor 2006), has been abandoned to a great extent in recent times.

\section{The structure of Les Oluges agroecosystem and its historical}

\section{transformation}

Les Oluges is a small village from La Segarra County, in Lleida (Catalonia) (Figure 1). It is located on the upper valley of the Sió River, at 490-650 m.a.s.l. The climate is dry continental Mediterranean, with cold and foggy winters and hot and dry summers. 
Average annual rainfall is below $500 \mathrm{~mm}$, and the period of water stress runs from April to October (Garrabou et al. 1999). Traditionally, cropland in La Segarra County was owned by small and medium-sized family farms. The capacity for irrigation was severely limited by the scarce volume of water of the Siò and Riera de Vergós rivers. These semiarid climate conditions limited crop yields and endangered harvests through recurrent draughts and frosts.

Figure 1. Map of Spain and Catalonia showing the location of Les Oluges.

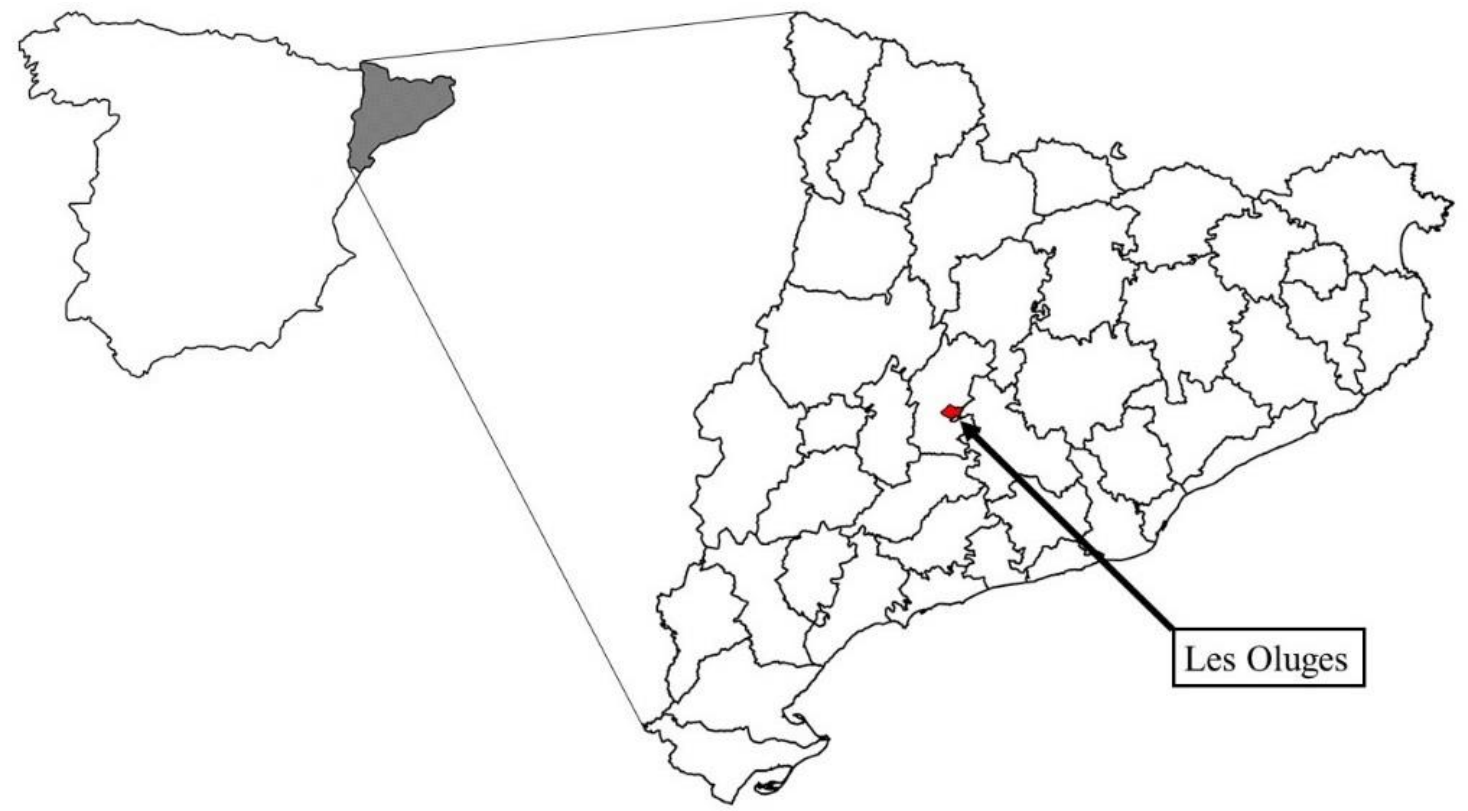

The agroecosystem of Les Oluges experienced important structural changes throughout the time span studied, as the size, composition, and interrelationships of its living funds were transformed. These changes can be outlined in three processes. 
Table 1. Composition of the main agroecosystem funds of Les Oluges in 1860, 1959 and 1999.

\begin{tabular}{|c|c|c|c|c|c|c|c|c|c|}
\hline \multicolumn{4}{|c|}{ Les Oluges - FUNDS } & \multirow{2}{*}{\multicolumn{2}{|c|}{$\frac{1860}{795}$}} & \multirow{2}{*}{\multicolumn{2}{|c|}{$\frac{1959}{404}$}} & \multirow{2}{*}{\multicolumn{2}{|c|}{$\frac{1999}{191}$}} \\
\hline \multirow{2}{*}{$\begin{array}{l}\text { Farming } \\
\text { community }\end{array}$} & \multicolumn{3}{|c|}{ Inhabitants } & & & & & & \\
\hline & \multicolumn{3}{|c|}{ Annual Working Units ${ }^{3}$} & \multicolumn{2}{|c|}{102} & \multicolumn{2}{|c|}{181} & \multicolumn{2}{|c|}{35} \\
\hline \multirow{9}{*}{$\begin{array}{l}\text { Farmland } \\
\text { (hectares) }\end{array}$} & \multirow{2}{*}{\multicolumn{2}{|c|}{ Cereals }} & Sown & 161 & \multirow{2}{*}{$36 \%$} & 515 & \multirow{2}{*}{$58 \%$} & 1,486 & $93 \%$ \\
\hline & & & Fallow & 161 & & 399 & & & \\
\hline & \multirow{5}{*}{ 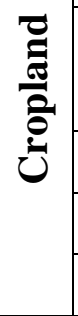 } & \multirow{2}{*}{$\begin{array}{l}\text { Associated } \\
\text { Crops }\end{array}$} & Sown & 422 & \multirow{2}{*}{$63 \%$} & 427 & \multirow{2}{*}{$36 \%$} & & \\
\hline & & & Fallow & 141 & & 139 & & & \\
\hline & & \multicolumn{2}{|l|}{ Others } & 4 & $1 \%$ & 93 & $6 \%$ & 76 & $5 \%$ \\
\hline & & \multicolumn{2}{|l|}{ Fallow } & & & & & 28 & $2 \%$ \\
\hline & & \multicolumn{2}{|l|}{ Total } & 888 & $47 \%$ & 1,573 & $84 \%$ & 1,591 & $84 \%$ \\
\hline & \multicolumn{3}{|c|}{ Pastureland } & 156 & $8 \%$ & 93 & $5 \%$ & 0.2 & $0 \%$ \\
\hline & \multicolumn{3}{|c|}{ Woodland \& scrubland } & 831 & $44 \%$ & 209 & $11 \%$ & 302 & $16 \%$ \\
\hline \multirow{8}{*}{ Livestock } & \multicolumn{3}{|c|}{ Horses } & \multicolumn{2}{|c|}{2} & \multicolumn{2}{|c|}{3} & & \\
\hline & \multicolumn{3}{|c|}{ Mules } & \multicolumn{2}{|c|}{56} & \multicolumn{2}{|c|}{120} & & \\
\hline & \multicolumn{3}{|c|}{ Donkeys } & \multicolumn{2}{|c|}{146} & \multicolumn{2}{|c|}{10} & & \\
\hline & \multicolumn{3}{|c|}{ Cows \& oxen } & & & & & 60 & \\
\hline & & Swines & & & & 8 & & 6,5 & \\
\hline & & Sheeps \& g & ats & & & 3 & & 50 & \\
\hline & & Fowl and ra & bits & & & 2,5 & & 369 , & \\
\hline & & LU500 & & & & 1 & & 3,0 & \\
\hline
\end{tabular}

First, from 1860 to 1999 there was a process of cropland expansion, particularly intense from 1860 to 1959 . Traditionally, cereals were the most widespread crop in Les Oluges, growing mainly wheat, barley, and rye. However, from the second half of the $19^{\text {th }}$ century the Phylloxera crisis in France created favourable market conditions that propelled vineyard expansion in Catalonia. This enlargement was carried out in Les Oluges by clearing woodland and using the traditional intercropping system in which cereals were grown between the widely-spaced rows of vines. The crop system that associated vines and cereals became the most abundant in 1860 (Table 1) (with 96\% of the cropland under associated crops corresponding to vines and cereals, and $4 \%$ to olive trees and cereals).

\footnotetext{
${ }^{3}$ http://ec.europa.eu/eurostat/statistics-explained/index.php/Glossary:Annual_work_unit_(AWU)
} 
In 1894 the Phylloxera plague reached the Segarra County ending the vineyard boom (JCA 1911), and the agroecosystem returned toward cereal production, substituting rye with oat. The presence of vines decreased (only $25 \%$ of associated crops corresponded to vines and cereals in 1959), but the alley crop association system was maintained with the introduction of olive and almond trees (Figure 2) (Pujadas i Rúbies et al. 1980). In 1999, grain monocultures took up most of the cropland, with barley being grown in $80 \%$ of the area of cereals.

Figure 2. Aerial pictures of Les Oluges in 1956. The image on the top shows a general overview of the village and the surrounding cropland; the bottom image shows the detail of the intercropping system. Source: Orthophotos of Catalonia in 1956-57 from the Institut Cartogràfic $i$ Geològic de Catalunya (ICGC), under licence CC BY-NC-SA 4.0.
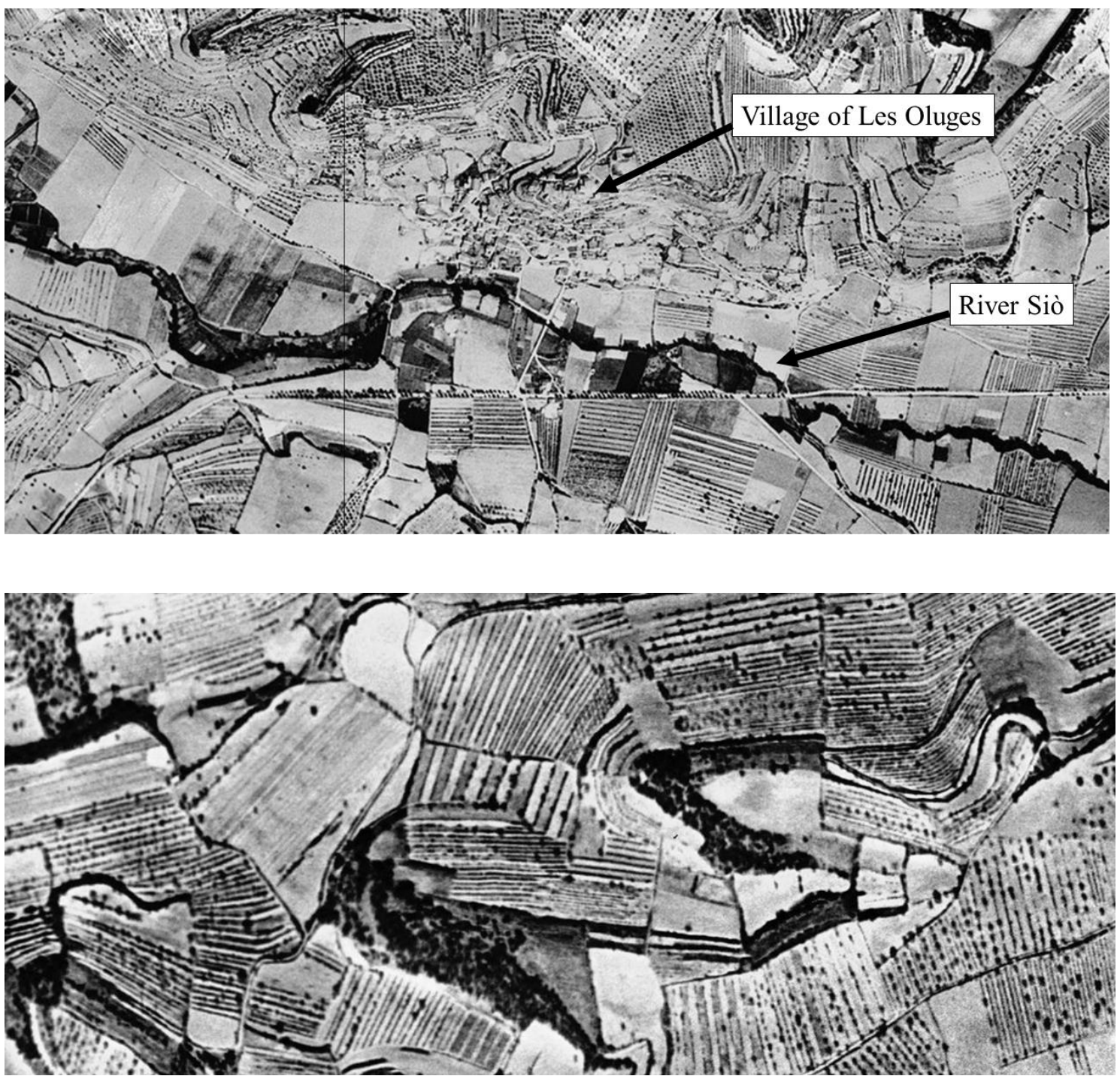
In addition to cropland enlargement there was also an increase in cropland productivity throughout the whole period (Table 2). This process was twofold: the introduction of new seeds and industrial fertilizers from the mid- $20^{\text {th }}$ century allowed, on the one hand, to increase yields and, on the other hand, reduced the need for fallow and therefore increased the area of cereals sown.

Table 2. Mean yields of the crops grown in Les Oluges in 1860, 1959 and 1999.

\begin{tabular}{|c|c|c|c|c|}
\hline \multicolumn{2}{|c|}{$\begin{array}{c}\text { CROP YIELDS } \\
\text { (kg fresh matter ha-1) }\end{array}$} & $\mathbf{1 8 6 0}$ & $\mathbf{1 9 5 9}$ & $\mathbf{1 9 9 9}$ \\
\hline \multirow{2}{*}{$\begin{array}{c}\text { Vegetable } \\
\text { gardens }\end{array}$} & Main produce & 8,675 & 9,392 & 26,078 \\
\cline { 2 - 5 } & By-products & 7,881 & 5,582 & 17,079 \\
\hline \multirow{2}{*}{ Cereals } & Main produce & 693 & 1,567 & 3,039 \\
\cline { 2 - 5 } & By-products & 1,442 & 2,855 & 3,138 \\
\hline \multirow{2}{*}{ Vines } & Main produce & 693 & 780 & \\
\cline { 2 - 5 } & By-products & 2,379 & 3,243 & \\
\hline \multirow{2}{*}{ Olive trees } & Main produce & 113 & 320 & 808 \\
\cline { 2 - 5 } & By-products & 1,195 & 4,520 & 14,037 \\
\hline \multirow{2}{*}{ Almonds } & Main produce & & 600 & 467 \\
\cline { 2 - 5 } & By-products & & 1,795 & 1,795 \\
\hline \multicolumn{2}{|c|}{ Fodder } & & & 18,178 \\
\hline
\end{tabular}

Secondly, the agroecosystem of Les Oluges experienced a continuous process of depopulation from 1860 to 1999 (Table 1). The farming community in 1999 was only one quarter of that in 1860. The agricultural crisis after the Phylloxera plague boosted agricultural migration to industrial centres and cities, and in the first half of the $20^{\text {th }}$ century the introduction of machinery, mineral fertilizers and new seeds increased labour productivity and reduced the need of agricultural workers.

Finally, the process of modernization of the agroecosystem affected also the composition and volume of the livestock-barnyard fund. From 1860 to 1959, livestock density decreased $18 \%$ (Table 1) because of the lower agrarian population and the introduction of new machinery that reduced the need for animal draft force. The greater availability of 
feeding resources allowed to substitute mules for donkeys and the availability of manure increased (Table 3) due to a reduced need for pasture (Díez et al. 2018). From 1959 to 1999 livestock density multiplied by 25 and animal husbandry was also transformed. While traditional livestock management was integrated in farmland, with animals feeding from by-products, domestic residues and grazing in less productive soils, under industrial management livestock was kept on feedlots and depended on feed imports.

Table 3. Manure availability and distribution among crop systems in Les Oluges in 1860, 1959 and 1999.

\begin{tabular}{|c|c|c|c|c|}
\hline \multicolumn{2}{|c|}{ MANURE } & 1860 & 1959 & 1999 \\
\hline \multicolumn{2}{|c|}{ Total available (kg fresh matter) } & $1,242,572$ & $1,540,252$ & $35,562,160$ \\
\hline \multirow{4}{*}{$\begin{array}{c}\text { Mean dose of } \\
\text { manure applied } \\
\text { on cropland } \\
(\mathrm{kg} \text { fresh matter } \\
\left.\mathrm{ha}^{-1}\right)\end{array}$} & Vegetable gardens & 10,184 & 10,000 & 20,000 \\
\hline & Cereals & 1,567 & 5,643 & 44,965 \\
\hline & Almonds & & & 19,841 \\
\hline & Irrigated olive trees & & & 34,391 \\
\hline
\end{tabular}

\section{Nutrient balance results}

\subsection{Aggregated scale}

Figure 3 shows the remarkable increase in the flows of nutrients in Les Oluges especially from 1959 to 1999 . The volume of nutrients extracted rose with cropland enlargement and increased cropland productivity, but the application of manure and industrial fertilizers made it possible to offset that greater extraction. However, while in 1860 and 1959 the input and output of nutrients were nearly balanced with total surplus and deficits between 1 and $-7 \mathrm{~kg} \mathrm{ha}^{-1}$ (see Table A1 in the Annex), in 1999 the volume of nutrients introduced in cropland was larger than the nutrients extracted, thus leading to total surpluses between 86 and $98 \mathrm{kh} \mathrm{ha}^{-1}$. 
Figure 3. Nutrient balances of Les Oluges in 1860, 1959 and 1999 at the aggregated scale.

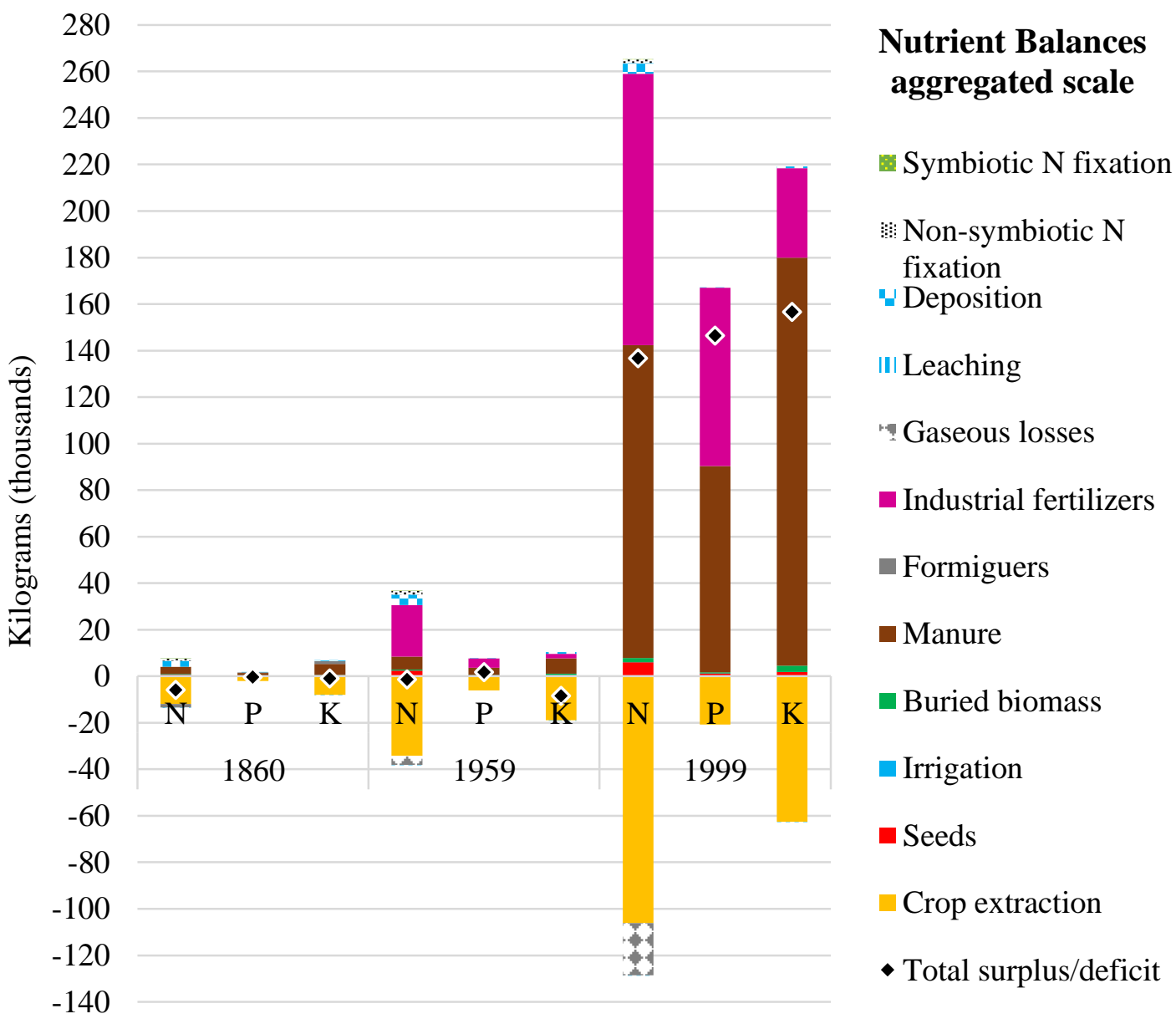

In 1860, the main input of nutrients came from manure, followed by atmospheric deposition (providing $48 \%$ and $10 \%$ of the nutrients extracted, respectively). However, in terms of fertilized area, formiguers were the most widespread management, since they were built in cereal monocultures and in the intercropping system that combined vines and cereals. Formiguers played an important role as input of nutrients: they provided $15 \%$ of the $\mathrm{P}$ and $\mathrm{K}$ extracted, but they had an initially negative impact on $\mathrm{N}$ increasing by $13 \%$ the human extraction of this nutrient.

In 1959 the nutrient balances improved for $\mathrm{N}$ and $\mathrm{P}$, but worsened for K. Again, the surpluses and deficits are not large enough to consider them determinant. The agroecosystem was functioning in a relative equilibrium of nutrient cycling, although it 
must be noted that the area and productivity of cropland were much higher in 1959 than in 1860 (Tables 1 and 2). The area fertilized with manure increased 63\%, providing an input of nutrients per hectare similar to that of 1860 . However, it was the introduction of mineral fertilizers which played a key role in the increased capacity of the agroecosystem for sustaining the higher nutrient extraction, even though this was achieved at the expense of the alien territories from where the guano and ammonium nitrate were extracted (Cushman 2013). Furthermore, the availability of these new fertilizing source enabled the abandonment of the use of formiguers, which required a large investment of labour.

Finally, the relative balance of inputs and outputs of nutrients changed in 1999. The extraction of nutrients increased more than three-fold between 1959 and 1999, while the input of nutrients multiplied by a factor of thirteen. Not only manure was widely available because of the greater livestock density, but the amount of industrial fertilizers applied also increased. Compared with 1959, in 1999 the area fertilized with industrial fertilizers increased $80 \%$, with a mean input of nutrients almost eight times larger. Along with the greater input of nutrients, natural losses also rose.

\subsection{Crop system scale}

When we look at the crop scale the distribution of the deficits and surpluses of nutrients can be qualified according to the management practices carried out on each crop system, which is related to the different value or importance given to each crop in the socioeconomic and cultural context. The results of the nutrient balances for every crop system in 1860, 1959 and 1999 are shown in Table A2 in the Annex. At the three points in time studied similar tendencies can be observed: cereal monocultures, which received the largest fertilizing effort, tended to achieve positive nutrient balances; while intercropping systems and woody crops monocultures tended to have nutrient deficits due to the scarce or total lack of fertilization. 
Given the large diversity of crop systems in Les Oluges, especially until the mid-20 th century, we will focus the analysis on the most widespread crop systems: cereal monocultures, and alley-cropping of vines and cereals in 1860 and 1959; and cereal monocultures and almond trees in 1999. In 1860 only cereals grown as monocrop achieved a positive balance of nutrients. According to the historical records, given the scarcity of manure it was applied in vegetable gardens, and in cereal monocultures when supply was sufficient. Additionally, wood from woodland was used to burn formiguers in the cereal land to supplement manure. These where the main inputs of nutrients in cereal monocultures, together with fallow (Figure 4a), and constituted a net input of nutrients from woodland and pastureland into cereal cropland (except for the nutrients recycled from the by-products fed to animals and reintroduced as manure). However, in the intercropping system fallow was the only technique that contributed a net input of nutrients (Figure 4b) as the other practices associated with the restoration of soil fertility were actually a recycling of the nutrients extracted through the by-products (formiguers in this crop system were built with vine pruning instead of wood from woodland). The intercropping of vines and cereals showed a negative balance of nutrients, but it must be highlighted that it was less pronounced in the case of vines and rye, which was the most widespread intercrop. 
Figure 4. Detail of the inputs and outputs of the main crop systems of Les Oluges in 1860.4a) Composition of the nutrient balances of cereals; 4b) Composition of the nutrient balances of the intercropping of vines and cereals.

4a)

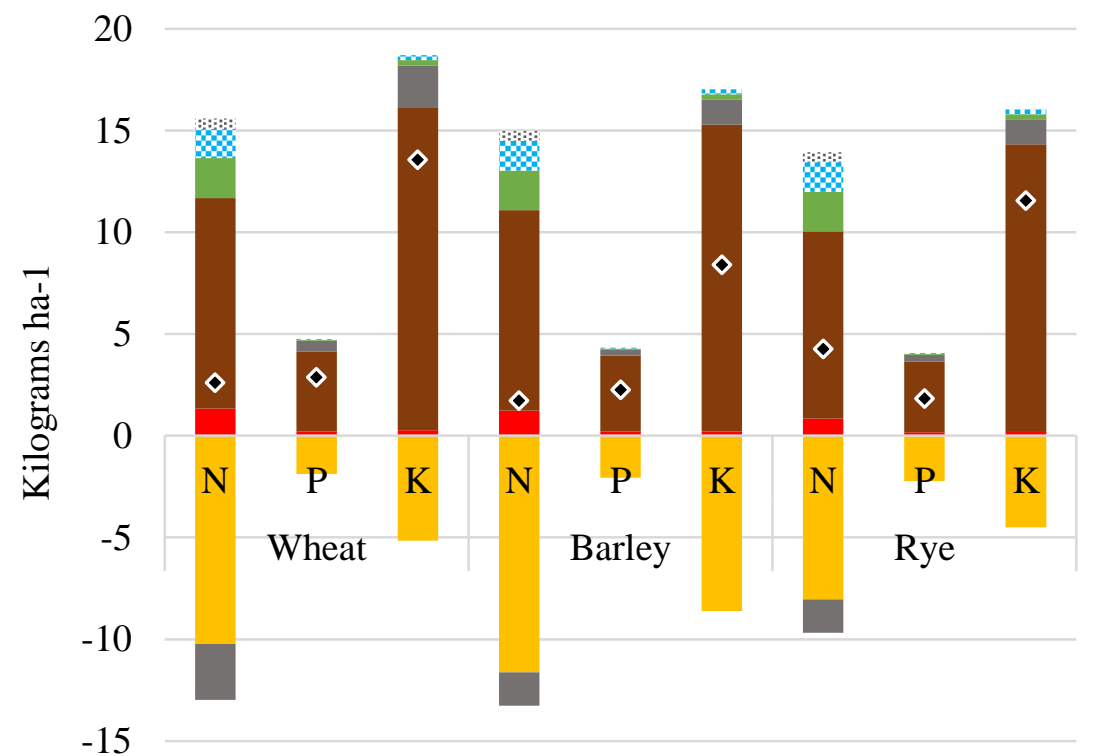

\section{Cereals, 1860}

7) Non-symbiotic $\mathrm{N}$

fixation

\&eposition

Fallow

- Formiguers

- Manure

- Seeds

- Crop extraction

- Total

4b)

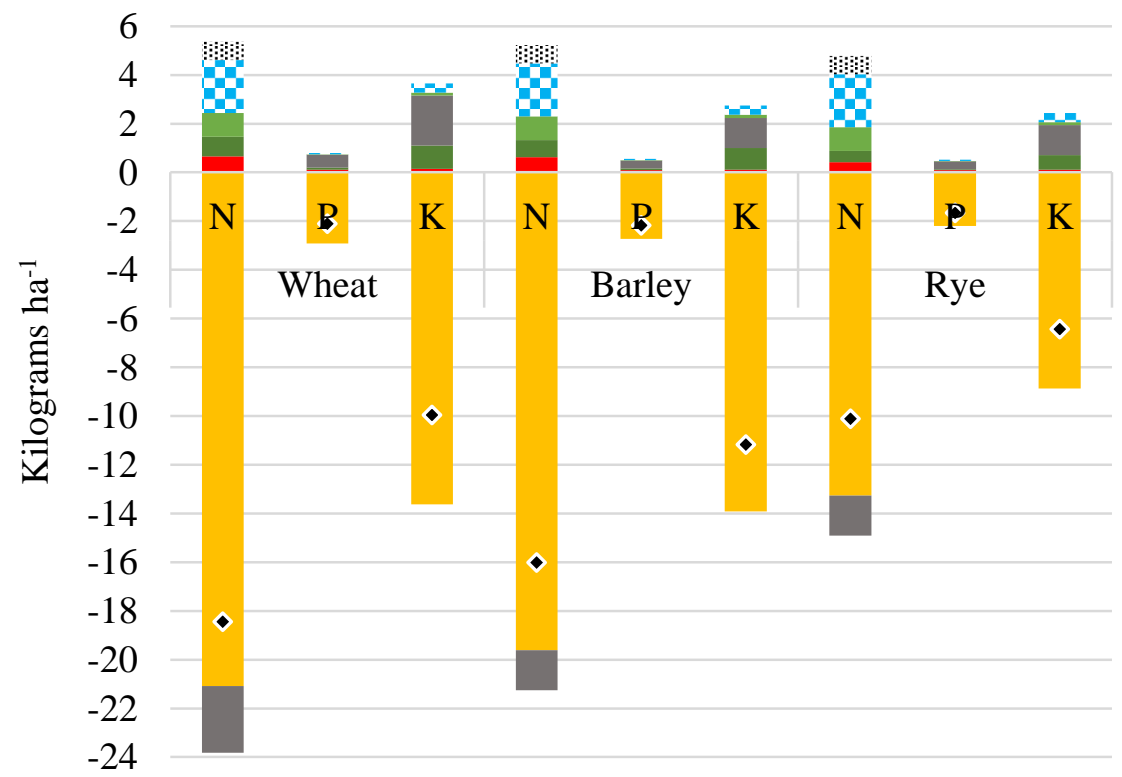

Vines \& cereals, 1860

Non-symbiotic

$\mathrm{N}$ fixation

Deposition

- Fallow

- Formiguers

- Buried biomass

- Seeds

Crop extraction

- Total 
In 1959 the situation was more complex. Most crop systems had nutrient deficits, especially for $\mathrm{N}$ and $\mathrm{K}$. The distribution of these deficits was determined to a great extent by the kind of fertilization applied on each type of crop. Taking this into consideration, our results show that those crop systems that received mineral fertilizers were more generally able to replenish the $\mathrm{N}$ extracted, though the application of manure provided a more balanced input of the three macronutrients (Figure 5).

Figure 5. Detail of the nutrient balances of the main crop systems of Les Oluges in 1959. 5a) Composition of the nutrient balances of rain-fed cereals; 5b) Composition of the nutrient balances of the intercropping of vines and cereals.

$5 a)$

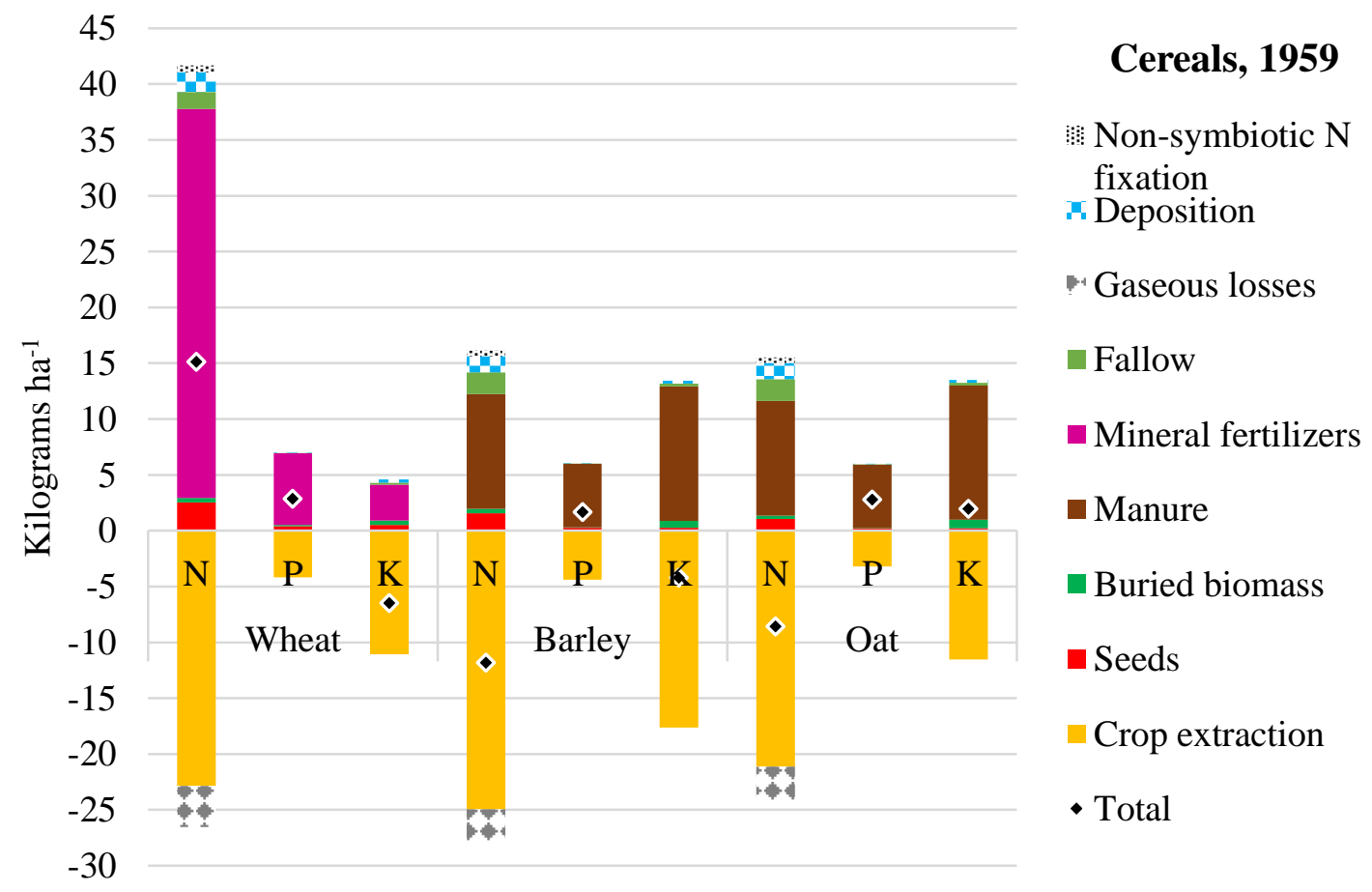


$5 b)$

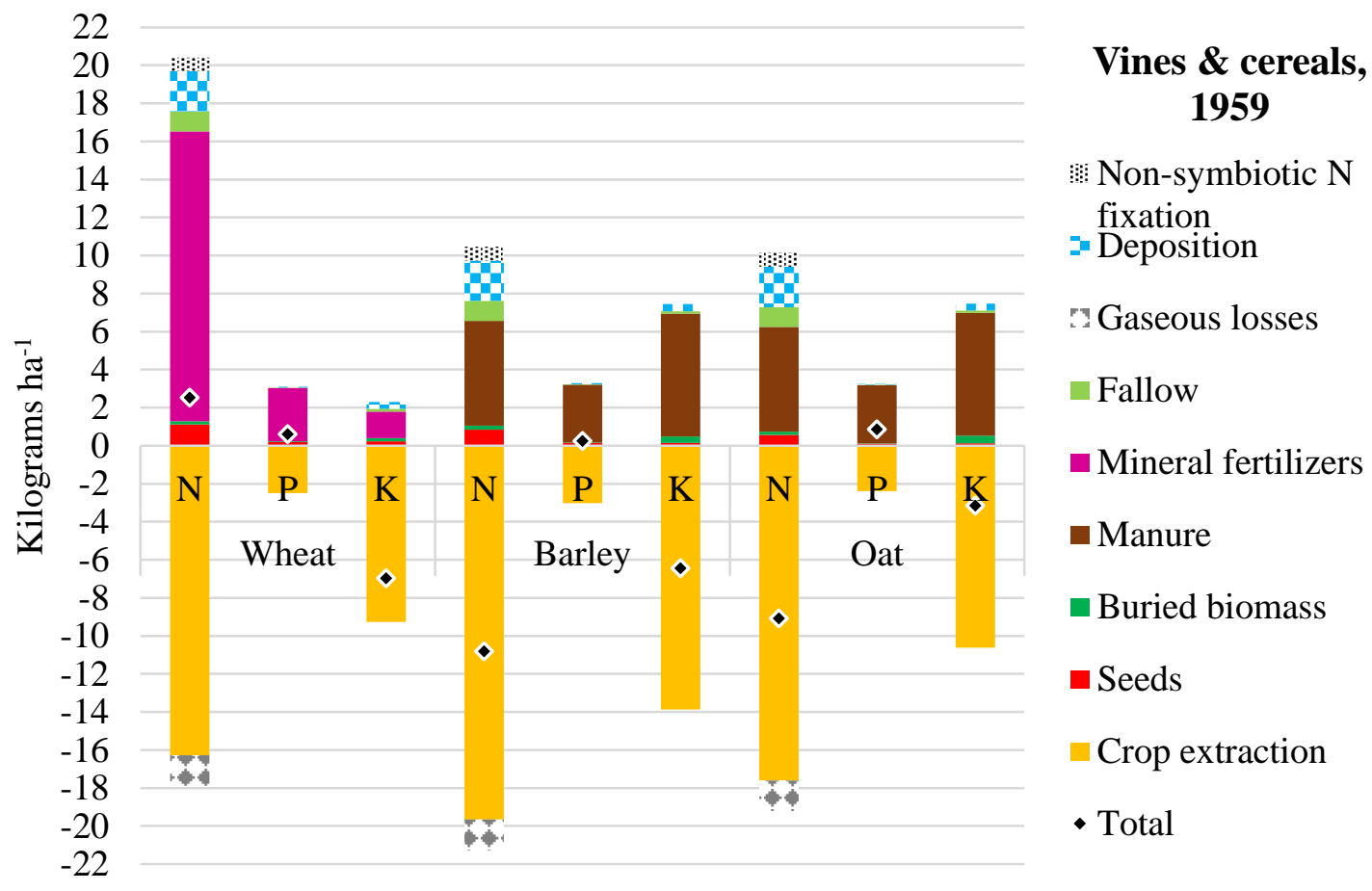

Given that there was a greater availability of fertilizers, all the crop systems which included cereals (as a single crop and in association with other crops) could receive either manure or mineral fertilizers. However, as the intercropping systems increased the number of species included, the surpluses of nutrients were reduced and deficits rose.

In 1999 the different management practices applied allow us to distinguish among woody crops and cereals, but there is no difference in the fertilization applied to wheat and barley. 
Figure 6. Detail of the nutrient balances of the main crop systems of Les Oluges in 1999. 6a) Composition of the nutrient balances of cereals; 6b) Composition of the nutrient balances of almonds.

6a)

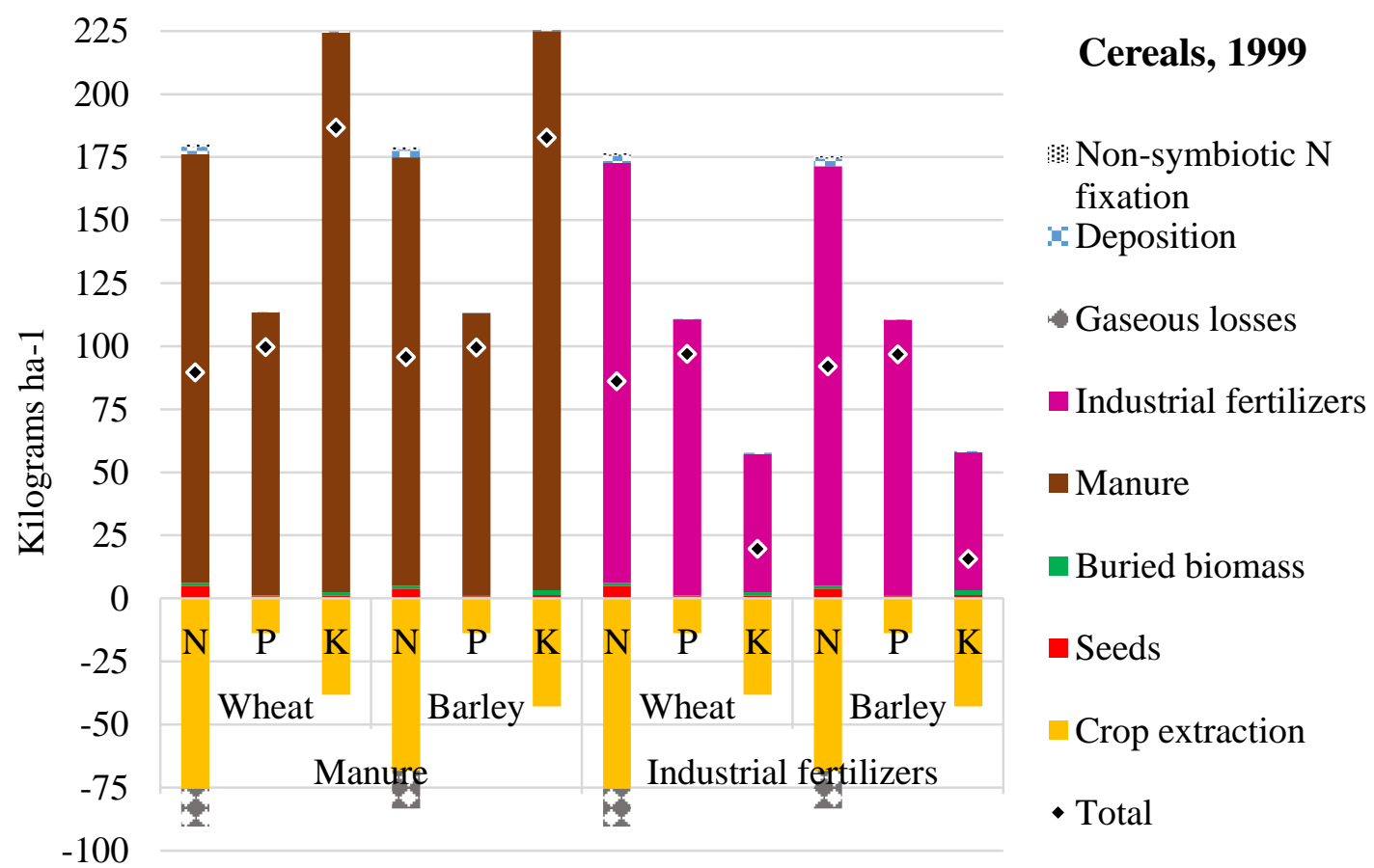

6b)

120

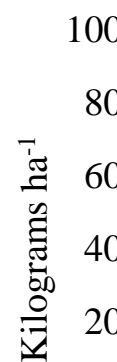

0

$-20$

$-40$

100
20

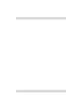

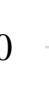

20

0

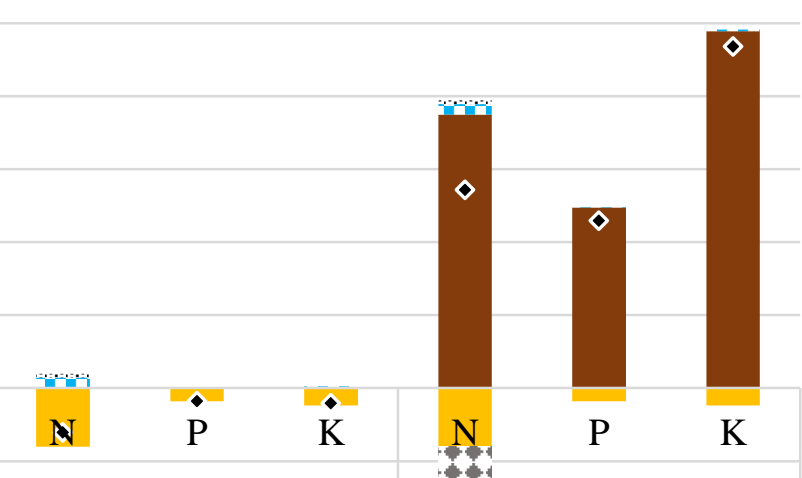

Non fertilized

\section{Almond trees,} 1999

: Non-symbiotic $\mathrm{N}$ fixation

Deposition

- Gaseous losses

- Manure

$\square$ Crop extraction

- Total

The availability of fertilizers escalated in 1999 , but their distribution remained unequal.

Cereal monocultures, which covered 93\% of cropland, obtained large surpluses of nutrients, either when fertilized with manure or with synthetic fertilizers (Figure 6a). Fallow was abandoned as a strategy for soil fertility management, and it became a way to obtain subsidies from the European Common Agricultural Policy (CAP). Woody crops 
received some fertilization with manure, but it was only applied in less than 10 hectares. The almond fields fertilized with manure had a largely positive balance of nutrients (Figure 6b), whereas manure applied on irrigated olive trees (with the maximum dose legally allowed) could not offset a negative balance of $\mathrm{N}$.

\section{Discussion}

\subsection{Changes in soil fertility management: efficiency, accomplishment and} durability

The results obtained from the nutrient balances of Les Oluges in 1860, 1959 and 1999 are relevant to examine the sustainability of the different management practices of soil fertility applied in each period from a combined perspective that evaluates their efficiency, accomplishment and durability.

Efficiency is assessed considering the capacity of these practices for balancing the nutrients extracted. In this sense, the nutrient balances of 1860 and 1959 can be considered more efficient than those of 1999. The former were close to equilibrium (Figure 3), meaning that nutrients might have been replenished even though the fertilizing resources available at the aggregated scale were quite scarce. Additionally, most of the deficits and surpluses at the crop system level were not severe (Table A2 in the Annex), which underlines the effort and ingenuity of farmers to sustain crop yields in a context of low availability of fertilizers that required a great investment of biomass recycling in order to reintroduce part of the nutrients extracted. On the contrary, the large surplus of nutrients in 1999 for some of the crop systems and at the aggregated scale reveals an excessive and inefficient use of fertilizers that could even damage cropland fertility in the long run. 
Accomplishment of the soil fertility management can be qualitatively understood from an agroecological perspective as the capacity of the fertilization techniques to contribute not only to the cycling of nutrients, but also to some of the other elements that determine soil fertility. An in-depth analysis of these elements would go beyond our possibilities, but it is possible to approximate some of the effects of certain management practices. First, we can assess the effects on three interrelated elements: soil organic matter content, soil biodiversity, and water and nutrient storage capacity. Among the fertilizers applied in Les Oluges, manure and buried biomass are the most important sources of organic matter (Figure 3). They were used in all the time points studied, with similar relevance in 1860 and 1999 (being 68\% and 62\% of the total nutrient inputs respectively) but with lower relevance in 1959 (being 42\% of the total nutrient inputs) (Table A1 in the Annex). Soil organic matter improves the capacity of the soil to retain water and nutrients, but also serves as food for soil biota, which performs multiple functions in soils and is of great importance for the sustainability and fertility of soils (Brussaard et al. 2007; Bardgett and Van Der Putten 2014; Gliessman 2015). Furthermore, belowground biodiversity is linked to aboveground biodiversity (Wardle et al. 2004; De Deyn and Van Der Putten 2005), which we estimate was greater in 1860 and 1959, when the various intercrops may have increased biodiversity at the crop system scale. Conversely, soil biota can be negatively affected by pesticides, herbicides and industrial inorganic fertilizers (Thiele-Bruhn et al. 2012). These are widely used in modern intensive agricultural systems, such as Les Oluges in 1999. Furthermore, pharmaceutical antibiotics used in intensive livestock farming, which are present in the manure applied in cropland, can also be detrimental for soil biodiversity. Finally, fallow and terraces were traditional management practices aimed to improve the nutrient and water storage capacity of soils in 1860 and 1959 that were vanishing in 1999. Thus, even though we cannot measure the effect of these 
practices in our historical analysis, it is possible to assert that the traditional practices employed in 1860 and 1959, when the agroecosystem was under an organic and mixed industrial-organic management, would have been better suited for the accomplishment of soil fertility than the industrial practices of 1999.

The durability of the soil fertility practices may be assessed considering the renewability or non-renewability of the fertilizers employed. In this respect, mineral and synthetic fertilizers obtained from finite natural resources and polluting industrial processes imply the unsustainability of the practices in 1959 and 1999. However, the renewability of fertilizing resources would also be endangered in 1860 when woodland was cleared for expanding cropland and by the extraction of biomass by grazing and to produce formiguers. In order to evaluate the durability of the management practices, we will connect the belowground and aboveground sustainability of the agroecosystem to complete our assessment.

\subsection{Belowground and aboveground sustainability}

The energy analysis of the farm system of Les Oluges developed in Díez et al. (2018) provides some insights on the aboveground dimension of the agroecosystem sustainability and emphasizes some of the results obtained from the belowground analysis.

First, the industrialized management of the agroecosystem in 1999 was not sustainable neither above- nor below-ground, despite its high productivity and the large availability of fertilizing resources. The energy efficiency of Les Oluges in 1999 was the lowest among the studied periods, as a result of the large increase of livestock density and the large dependence on external inputs that reduced and partially replaced the energy recirculated within the agroecosystem. In 1999 Les Oluges required two units of energy 
for each unit of energy produced, and introduced more than 4 units of macronutrients per unit of macronutrient output.

Secondly, the aboveground and belowground analyses emphasize the relevance of the integrated management of farmland funds usually found in organic farm systems (Kraussmann 2004; Tello et al. 2012; Gingrich et al. 2015) with livestock and biomass recycling playing a key role. Soil fertility practices in 1860 and 1959 were better able to balance nutrient cycling with a lower dependency on external inputs and, additionally they were better adapted to assess the multiple processes that affect soil fertility. The energy analysis of Les Oluges in 1860, and especially in 1959, revealed an agroecosystem that was able to combine biomass reuses and external inputs so that provision for human purposes and farm associated biodiversity (which is linked to the provision of ecological services) were reasonably balanced.

The historical evolution analysed in Les Oluges is similar to that shown at the national territory by Guzmán et al. (2018), which reveals a general tendency in throughout the second half of the $20^{\text {th }}$ century towards an agrarian metabolism based on an increased use of external inputs and a reduction of internal loops (biomass reuses and recycling) that had negative effects on soils and biodiversity, and deteriorated the efficiency and productive capacity of agroecosystems.

However, the sustainability of the traditional agroecosystem managements of Les Oluges in 1860 and 1959 needs to be further qualified. The intensive use of woodland and the deforestation process in 1860 could not have continued indefinitely, and would have ultimately compromised the sustainability of the agroecosystem. The arrival of the Phylloxera plague and the introduction of mineral fertilizers and modern machinery changed the socioeconomic context and technological possibilities of Les Oluges. 
Mineral fertilizers reduced the local land cost of the agroecosystem sustainability (Guzmán et al. 2011) by diminishing the need for fallow and importing nutrients from distant territories, instead of transferring them from woodland and pastureland. Additionally, the new industrial inputs reduced the labour needed to manage the agroecosystem. However, the beginning of the industrialized management was combined with some traditional features that proved useful for the sustainability of the agroecosystem. External inputs were complemented with the recirculation of nutrients through biomass reuse. The dependence on non-renewable resources that the introduction of modern technologies implied could probably be environmentally bearable as long as these industrial inputs were used at a small scale, but it introduces a new tension between the sustainability at the local and global scales: a metabolic rift (Bellamy 1999).

\section{Conclusions}

Sustainable management of agroecosystems has been a hard task throughout history. The aboveground and belowground analysis presented in this paper reveals that the challenges faced and the solutions adopted to keep farm systems sustainable over time depended on multiple dimensions, and have been affected by different ecological, technological and socioeconomic factors. However, sustainability is not a fixed condition, but a dynamic process. In this sense, the results of our historical analysis reflect that a more productive agroecosystem does not mean a more sustainable one. The main reason for that is having given up the sustenance effort devoted to reproduce the living funds of the agroecosystem through local renewable biomass flows by keeping a multi-purpose and integrated management adapted to the site-specific ecological and socioeconomic conditions. Reducing the dependence on external inputs of industrial origin, coming directly or indirectly from non-renewable fossil fuels, by increasing biomass reuses and integrated agroecosystem management can be a way to improve the sustainability of current farm 
systems. Sustainable management of agroecosystems needs to deal with different tensions and balances, and our case study reflects the strain over the renewability of resources and between different scales of analysis: crop system, agroecosystem and, ultimately, global levels. In order to deal with these tensions and multiple balances of the art of farming (Netting 1993; Van der Ploeg 2013), the study of traditional integrated management practices can offer useful insights for better prospects of sustainability.

Acknowledgments: We would like to thank Xavier Mestre, Josep Maria Llenes and Vicent Torres for their information about the agricultural managements in 1959 and 1999.

Data Availability: The data analysed for the study are available from the corresponding author on request.

\section{Compliance with Ethical Standards}

Conflict of Interest: The authors declare that they have no conflict of interest. 


\section{References}

Agnoletti, M., and Emanueli, F. (Eds.). (2016). Biocultural Diversity in Europe. https://doi.org/10.1007/978-3-319-26315-1

Altieri, M. A. (2004). Linking ecologists and traditional farmers in the search for sustainable agriculture. Frontiers in Ecology and the Environment, 2(1), 35-42. https://doi.org/10.1890/1540-9295(2004)002[0035:LEATFI]2.0.CO;2

Bardgett, R. D., and Van Der Putten, W. H. (2014). Belowground biodiversity and

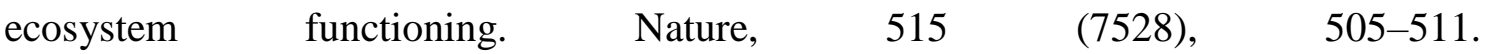
https://doi.org/10.1038/nature13855

Barthel, S., Crumley, C., and Svedin, U. (2013). Bio-cultural refugia - Safeguarding diversity of practices for food security and biodiversity. Global Environmental Change, 23(5), 1142-1152. https://doi.org/10.1016/j.gloenvcha.2013.05.001

Bellamy, J. (1999). Marx 's Theory of Metabolic Rift: Classical Foundations for Environmental Sociology. American Journal of Sociology, 105(2), 366-405.

Bignal, E. M., and McCracken, D. I. (2000). The nature conservation value of European traditional farming systems. Environmental Reviews, 8(3), 149-171. https://doi.org/10.1139/er-8-3-149

Blondel, J. (2006). The "design" of Mediterranean landscapes: A millennial story of humans and ecological systems during the historic period. Human Ecology, 34(5), 713729. https://doi.org/10.1007/s10745-006-9030-4

Bosch Serra, A. D., Iglesias Fernández, N., Amat Bové, M., and Boixadera Llobet, J. (2007). Efficiency of nitrogen in slurry and mineral fertilisation under rain-fed 
Mediterranean agriculture. In A. D. Bosch Serra, M. R. Teira Esmatges, and J. M. Villar Mir (Eds.), Towards a better efficeincy in $\mathrm{N}$ use. Universitat de Lleida.

Brussaard, L., de Ruiter, P. C., and Brown, G. G. (2007). Soil biodiversity for agricultural sustainability. Agriculture, Ecosystems and Environment, 121(3), 233-244. https://doi.org/10.1016/j.agee.2006.12.013

Cushman, G. T. (2013). Guano and the Opening of the Pacific World: A Global Ecological History. Cambridge: Cambridge University Press.

De Deyn, G. B., and Van Der Putten, W. H. (2005). Linking aboveground and belowground diversity. Trends in Ecology and Evolution, 20(11), 625-633. https://doi.org/10.1016/j.tree.2005.08.009

Díez, L., Cussó, X., Padró, R., Marco, I., Cattaneo, C., Olarieta, J. R., Garrabou, R. and Tello, E. (2018). More than energy transformations: A historical transition from organic to industrialised farm systems in a Mediterranean village (Les Oluges, Catalonia, 18601959-1999). International Journal of Agricultural Sustainability, 16(4-5), 399-417. https://doi.org/10.1080/14735903.2018.1520382

Eichhorn, M. P., Paris, P., Herzog, F., Incoll, L. D., Liagre, F., Mantzanas, K., Mayus, M., Moreno, G., Papanastasis, P., Pilbeam, D. J., Pisanelli, A., and Dupraz, C. (2006). Silvoarable systems in Europe - Past, present and future prospects. Agroforestry Systems, 67(1), 29-50. https://doi.org/10.1007/s10457-005-1111-7

Fernández-Escobar, R., Sánchez-Zamora, M. A., García-Novelo, J. M., and MolinaSoria, C. (2015). Nutrient removal from olive trees by fruit yield and pruning. HortScience, 50(3), 474-478. 
Galán del Castillo, E. (2015). Socio Ecological Transition of Organic Agricultures in Catalonia (late 19th-20th century). https://doi.org/B 11617-2015

Garcia-Ruiz, R., González de Molina, M., Guzmán, G., Soto, D., and Infante-Amate, J. (2012). Guidelines for Constructing Nitrogen, Phosphorus, and Potassium Balances in Historical Agricultural Systems. Journal of Sustainable Agriculture, 36(6), 650-682. https://doi.org/10.1080/10440046.2011.648309

Garrabou, R., Naredo, J. M., and Ávila Cano, J. C. (1999). El Agua en los sistemas agrarios: una perspectiva histórica. Madrid: Visor.

Garrabou, R., and González de Molina, M. (2010). La reposición de la fertilidad en los sistemas agrarios tradicionales. Icaria.

Gingrich, S., Haidvogl, G., Krausmann, F., Preis, S., and Garcia-Ruiz, R. (2015). Providing Food while Sustaining Soil Fertility in Two Pre-industrial Alpine Agroecosystems. Human Ecology, 43(3), 395-410. https://doi.org/10.1007/s10745-015$\underline{9754-0}$

Gliessman, S. R. (2015). Agroecology: The ecology of sustainable food systems. CRC Press.

González de Molina, M., and Toledo, V. M. (2014). The social metabolism: a socioecological theory of historical change. Cham: Springer.

Guzmán, G. I., González de Molina, M., and Alonso, A. M. (2011). The land cost of agrarian sustainability. An assessment. Land Use Policy, 28(4), 825-835. https://doi.org/10.1016/j.landusepol.2011.01.010

Guzmán, G. I., Aguilera, E., García-Ruíz, R., Torremocha, E., Soto-Fernández, D., Infante-Amate, J., and González de Molina, M. (2018). The agrarian metabolism as a tool 
for assessing agrarian sustainability, and its application to Spanish agriculture (19602008). Ecology and Society, 23(1):2. https://doi.org/10.5751/ES-09773-230102

Harris, P. J. (1988). Microbial transformations of nitrogen. In A. Wild (Ed.), Russell's Soil Conditions and Plant Growth (pp. 608-651). Longman.

JCA (1890). Avance Estadístico sobre el cultivo del cereal y de leguminosas asociadas en España. Dirección General de Agricultura, Industria y Comercio.

JCA (1911). La invasión filoxérica en España y estado en 1909 de la reconstrucción del viñedo.

Krausmann, F. (2004). Milk, manure, and muscle power. Livestock and the transformation of preindustrial agriculture in Central Europe. Human Ecology, 32(6), 735-772. https://doi.org/10.1007/s10745-004-6834-y

Martin, J. F., Roy, E. D., Diemont, S. A. W., and Ferguson, B. G. (2010). Traditional Ecological Knowledge (TEK): Ideas, inspiration, and designs for ecological engineering. Ecological Engineering, 36(7), 839-849. https://doi.org/10.1016/j.ecoleng.2010.04.001

Mestre, C., and Mestres, A. (1949). Aportación al estudio de la fertilización del suelo por medio de hormigueros (Vol. 109).

Neary, D. G., Klopatek, C. C., DeBano, L. F., and Folliott, P. F. (1999). Fire effects on belowground sustainability: A review and synthesis. Forest Ecology and Management, 122(1-2), 51-71. https://doi.org/10.1016/S0378-1127(99)00032-8

Netting, RMC (1993). Smallholders, householders: farm families and the ecology of intensive, sustainable agriculture. Stanford (CA): Stanford Univeristy Press.

Öborn, I., Edwards, A. C., Witter, E., Oenema, O., Ivarsson, K., Withers, P. J. A., Nilsson, S. I., and Richert Stinzing, A. (2003). Element balances as a tool for sustainable nutrient 
management: A critical appraisal of their merits and limitations within an agronomic and environmental context. European Journal of Agronomy, 20(1-2), 211-225. https://doi.org/10.1016/S1161-0301(03)00080-7

Oenema, O., Kros, H., and De Vries, W. (2003). Approaches and uncertainties in nutrient budgets: Implications for nutrient management and environmental policies. European Journal of Agronomy, 20(1-2), 3-16. https://doi.org/10.1016/S1161-0301(03)00067-4

Olarieta, J. R., and Padró, R. (2016). Investment in Landesque Capital in Semiarid Environments: Dry-Stone Terraces in Les Oluges (La Segarra, Catalunya). Annales-Anali Za Istrske in Mediteranske Studije - Series Historia et Sociologia, 26(3), 487-498. https://doi.org/10.19233/ASHS.2016.29

Olarieta, J. R., Padró, R., Masip, G., Rodríguez-Ochoa, R., and Tello, E. (2011). "Formiguers", a historical system of soil fertilization (and biochar production?). Agriculture, Ecosystems and Environment, 140(1-2), 27-33. https://doi.org/10.1016/j.agee.2010.11.008

Oliver, Y. M., Robertson, M. J., and Weeks, C. (2010). A new look at an old practice: Benefits from soil water accumulation in long fallows under Mediterranean conditions. $\begin{array}{llll}\text { Agricultural } \quad \text { Water } & \text { Management, }\end{array}$ https://doi.org/10.1016/j.agwat.2010.08.024

Peoples, M. B., Bowman, A. M., Gault, R. R., Herridge, D. F., McCallum, M. H., McCormick, K. M., Norton, R. M., Rochester, I. J., Scammell, G. J., and Schwenke, G. D. (2016). Factors regulating the contributions of fixed nitrogen by pasture and crop legumes to different farming systems of eastern Australia. Plant and Soil, 228 (1), 29-41. 
Plieninger, T., Höchtl, F., and Spek, T. (2006). Traditional land-use and nature conservation in European rural landscapes. Environmental Science and Policy, 9(4), 317321. https://doi.org/10.1016/j.envsci.2006.03.001

Pujadas i Rúbies, R., Solé i Roig, S., and Pujadas, I. (1980). L’Economia de la Segarra: Especialització agrícola i desenvolupament ramader. Barcelona: Caixa d'Estalvis de Catalunya.

Roxas Clemente, S. (1808). Sobre los hormigueros u hornillos. Semanario de Agricultura y Artes, (588), 209-216.

Sandor, J. A. (2006). Ancient Agricultural Terraces and Soils. In B. P. Warkentin (Ed.), Footprints in the Soil. Amsterdam: Elsevier.

Shiel, R. S. (2006). Nutrient Flows in Pre-Modern Agriculture in Europe. In J. R. McNeill and V. Winiwarter (Eds.), Soils and Societies. Perspectives from Environmental History. The White Horse Press.

Soroa, J. M. (1953). Prontuario del agricultor y el ganadero (Dossat, Ed.). Madrid.

Tello, E., Garrabou, R., Cussó, X., Olarieta, J. R., and Galán, E. (2012). Fertilizing Methods and Nutrient Balance at the End of Traditional Organic Agriculture in the Mediterranean Bioregion: Catalonia (Spain) in the 1860s. Human Ecology, 40(3), 369383. https://doi.org/10.1007/s10745-012-9485-4

Thiele-Bruhn, S., Bloem, J., de Vries, F. T., Kalbitz, K., and Wagg, C. (2012). Linking soil biodiversity and agricultural soil management. Current Opinion in Environmental Sustainability, 4(5), 523-528. https://doi.org/10.1016/j.cosust.2012.06.004

Vicedo i Rius, E., Boixadera Llobet, J., and Olarieta Alberdi, J. R. (1999). Sistema hidráulico, organización de los riego y usos del agua de la huerta de Lleida (1830-1959). 
In El agua en los sistemas agrarios, (pp. 225-274). Fundación Argentaria, Visor Ediciones.

Wardle, D. A., Bardgett, R. D., Klironomosw, J. N., Setala, H., Putten, W. H. van der, and Wall, D. H. (2004). Ecological Linkages Between Aboveground and Belowground Biota. Science, 304(June), 1629-1633. https://doi.org/10.1126/science.1094875 



\section{A. Annex}

Table A1. Detail of the flows of nutrients and the total surplus/deficit of the nutrient balances of Les Oluges in 1860, 1959 and 1999 at aggregated scale. The hectares refer to the total surface on which the flow of nutrients occur. The figures of $\mathrm{N}, \mathrm{P}$ and $\mathrm{K}$ refer to the mean $\mathrm{kg} \mathrm{ha}{ }^{-1}$ of each flow.

\begin{tabular}{|c|c|c|c|c|c|c|c|c|c|c|c|c|}
\hline \multirow{2}{*}{$\begin{array}{l}\text { Nutrient balances } \\
\text { Aggregated scale }\end{array}$} & \multicolumn{4}{|c|}{1860} & \multicolumn{4}{|c|}{1959} & \multicolumn{4}{|c|}{1999} \\
\hline & $\mathbf{H a}$ & $\mathbf{N}$ & $\mathbf{P}$ & $\mathbf{K}$ & Ha & $\mathbf{N}$ & $\mathbf{P}$ & $\mathbf{K}$ & Ha & $\mathbf{N}$ & $\mathbf{P}$ & $\mathbf{K}$ \\
\hline Crop extraction & 888 & -13.40 & -2.35 & -8.98 & 1573 & -21.77 & -3.90 & -12.02 & 1591 & -66.78 & -13.05 & -39.38 \\
\hline Seeds & 306 & 2.04 & 0.38 & 0.46 & 929 & 2.57 & 0.42 & 0.51 & 1492 & 4.03 & 0.86 & 1.23 \\
\hline Irrigation & 4 & 2.90 & 0.07 & 1.83 & 8 & 2.41 & 0.05 & 1.52 & 4 & 2.64 & 0.06 & 1.66 \\
\hline Buried biomass & 422 & 0.70 & 0.07 & 0.91 & 941 & 0.48 & 0.10 & 0.62 & 1487 & 1.24 & 0.23 & 1.83 \\
\hline Manure & 165 & 19.01 & 7.20 & 29.14 & 269 & 20.82 & 11.50 & 24.39 & 795 & 169.10 & 111.59 & 220.70 \\
\hline Formiguers & 570 & -2.72 & 0.53 & 2.04 & & & & & & & & \\
\hline Industrial fertilizers & & & & & 389 & 56.75 & 10.47 & 5.23 & 701 & 166.45 & 109.46 & 54.73 \\
\hline Gaseous losses & 4 & -8.5 & & & 658 & -6.03 & & & 1496 & -14.96 & & \\
\hline Leaching & 4 & -7.5 & & -3.5 & 8 & -7.5 & & -3.5 & 4 & -7.5 & & -3.5 \\
\hline Deposition & 888 & 2.90 & 0.07 & 0.50 & 1573 & 2.90 & 0.07 & 0.50 & 1591 & 2.90 & 0.07 & 0.50 \\
\hline Non-symbiotic $\mathrm{N}$ fixation & 888 & 1.00 & & & 1573 & 1.00 & & & 1591 & 1.00 & & \\
\hline Symbiotic N fixation & 4 & 22.41 & & & 5 & 22.41 & & & 5 & 13.09 & & \\
\hline Total surplus/deficit & & $-7( \pm 0)$ & $0( \pm 0)$ & $-1( \pm 0)$ & & $-1( \pm 0)$ & $1( \pm 0)$ & $-5( \pm 0)$ & & $86( \pm 21)$ & $92( \pm 14)$ & $98( \pm 7)$ \\
\hline
\end{tabular}


Table A2. Per hectare nutrient balances of the crop systems of Les Oluges in 1860, 1959 and 1999.

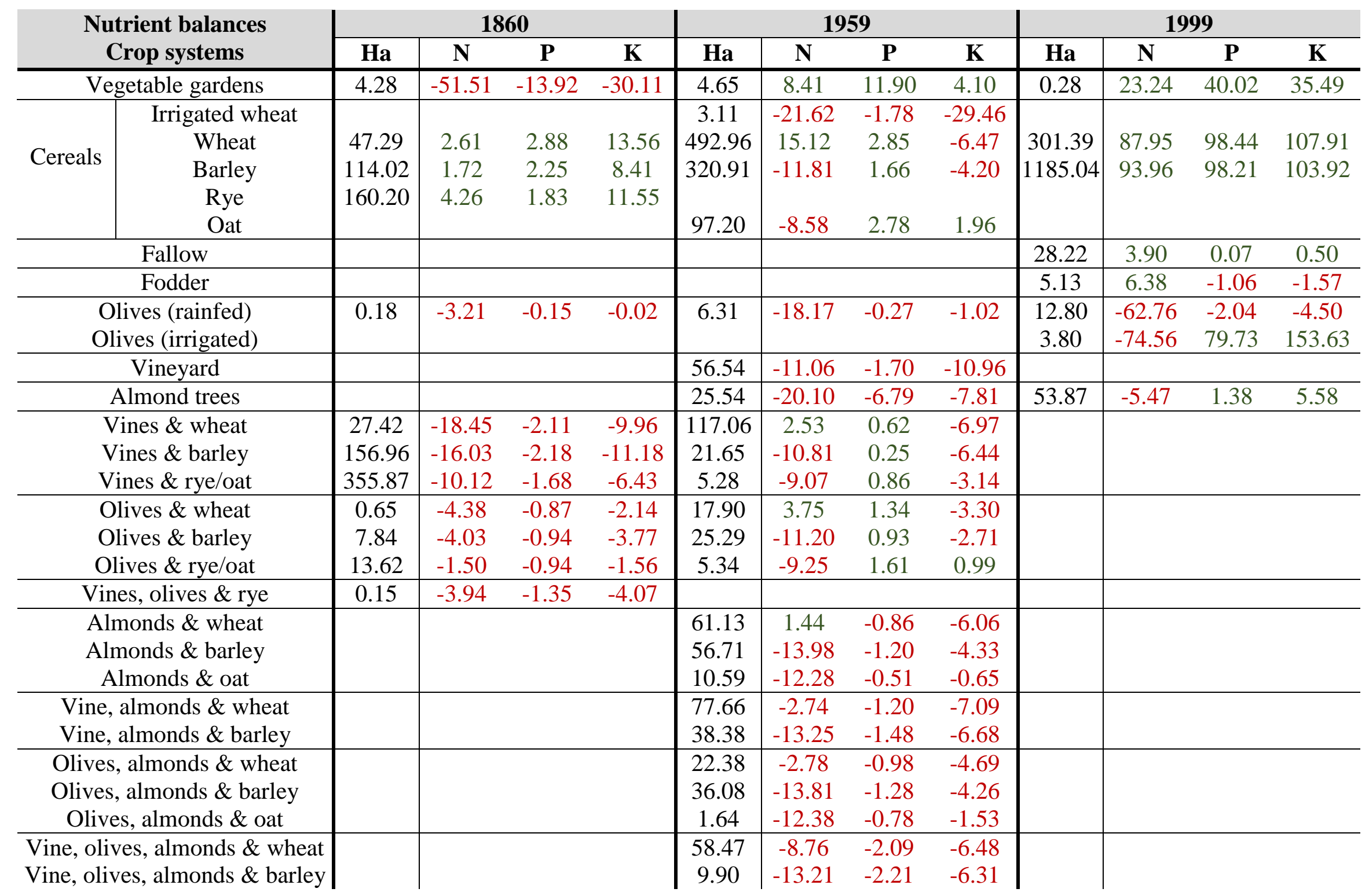

